\title{
5.2 Люмінесцентні властивості плівок оксиду алюмінію та їх застосування в якості сенсорів
}

Спостережуваний в останні роки підвищений інтерес до вивчення умов утворення і дослідженню люмінесцентних властивостей матеріалів на основі оксиду алюмінію обумовлений необхідністю створення і вдосконалення економічних джерел світла і радіаційних дозиметрів для реєстрації всіх типів радіаційного випромінювання в навколишньому середовищі. Люмінесцентні методи контролю використовуються для визначення вмісту різних шкідливих сполук в пробах стічних вод [268,269].

Вода більшості поверхневих джерел водопостачання характеризується помірним і високим рівнем забруднення. Пріоритетними забруднювачами протягом багатьох років залишаються органічні сполуки, зважені речовини, нафтопродукти, феноли, важкі метали та ін. Оскільки не існує способів визначення речовин, в однаковій мірі чутливих для різних сполук, потрібно підбирати оптимальні методи, застосовувати особливі прийоми підготовки проб води, що спрощують ідентифікацію забруднюючих речовин і їх подальше кількісне визначення. Тому питання застосування нових чутливих і експресних методів для визначення як хімічних, так і біологічних показників актуальні і постійно затребувані при організації контролю якості води.

Раніше була встановлена можливість запасання світлосумми оксидами металів при їх взаємодії з парами води в результаті їі дисоціації на поверхні твердого тіла [270]. Передбачалося, що світіння ряду напівпровідникових матеріалів в контакті з електролітом визначається енергетичними параметрами центрів, утворених адсорбованими на поверхні гідроксил іонами, які виконують функцію донорів, з локалізованими на них електронами [268,271]. Для з'ясування механізму люмінесценції оксидної плівки, зануреної в електроліт, як і при вивченні інших видів люмінесценції, значний інтерес представляє вивчення кінетики світіння. 
В якості основи люмінесцентного сенсора використовувалися люмінесцентні структури $\mathrm{Al}-\mathrm{Al}_{2} \mathrm{O}_{3}-\mathrm{SnO}_{2}$ i напівпровідникові плівки $\mathrm{CdS}$. Оксидні плівки алюмінію отримувались електрохімічним окисленням алюмінієвої фольги у водному розчині (0,5 - 1\%) щавлевої кислоти. Напруга формування становила 30 - 70 В, час формування 40 - 90 хвилин, що дозволяло отримувати плівки товщиною 30 - 50 мкм. Одним з електродів до плівки $\mathrm{Al}_{2} \mathrm{O}_{3}$ використовувалась алюмінієва фольга. В якості другого електрода використовувались шари $\mathrm{SnO}_{2}$, нанесені на оксидну плівку методом піролізу $\mathrm{SnCl}_{4}$ [268]. Осцилограми яскравості світіння вимірювалися на установці, що складається 3 світлонепроникної камери, фільтра, що поглинає ІЧвипромінювання, фотоелектронного помножувача ФЭУ-100, вимірювача малих струмів ИМТ-005 i двохпроменевого осцилографа С8-17. Сигнал після посилення з анода ФЭУ-100 подавався на вхід осцилографа.

Прикладена синусоїдальна напруга до досліджуваного люмінофора, зануреного в електроліт, призводить до появи хвиль яскравості в кожен 3 напівперіодів напруги. Інтенсивність світіння в катодний і анодний напівперіоди можуть істотно відрізнятися один від одного. Однак i в разі електролюмінесценції тонких плівок спостерігаються хвилі яскравості світіння і в анодний, і в катодний напівперіоди. У зв'язку з труднощами інтерпретації кінетики розглянутого світіння люмінофорів в контакті з електролітом були проведені дослідження кінетики світіння при збудженні однополярними імпульсами напруги. Для більш повного вивчення впливу іонів електроліту на механізм світіння вивчалася також і кінетика світіння при збудженні напругою в формі двохполярної меандри. Це призводило до чіткого розмежування позитивних i негативних іонів електроліту, що надходять до поверхні досліджуваного матеріалу, при одній і тій же величині збуджуючої напруги, як в анодний, так і катодний напівперіоди.

Вивчення кінетики світіння при порушенні однополярним позитивними імпульсами напруги ( «+» на зразку) проводилося з плівками, зануреними в ряд 
водних електролітів, для яких залежність інтенсивності світіння від величини pH проходить через максимум. В цьому випадку у збудженні світіння беруть участь як іони $\mathrm{OH}^{-}$, так $H^{+}$. Температура електроліту підтримувалася постійною i становила $295 K$. На осцилограмі яскравості світіння спостерігаються піки світіння, як в напівперіод, коли подавалася напруга, так і в напівперіод, коли поле відсутнє. Видимий спалах світіння в напівперіод, коли відсутня прикладається напруга, з'являється при амплітудах напруги $2-3 B$. Однак інтенсивність цього свічення незначна. Збільшення амплітуди прикладається напруги, що прикладається, призводить до появи спалаху в анодний напівперіод i збільшення яскравості світіння в напівперіод, коли збудження електричним полем відсутнє.

Істотний вплив на інтенсивність і форму хвилі світіння надавала частота напруги, що прикладається. Так, з ростом частоти від 25 до 250 Гц інтенсивність світіння в анодний напівперіод істотно зменшується, а в напівперіод, коли напруга відсутня, інтенсивність світіння до деякого значення не залежить від його величини, а потім починає зменшуватися. Форма хвилі яскравості світіння залежить також і від типу використовуваного електроліту. Причому, якщо на інтенсивність світіння в анодний напівперіод це не мало значного впливу, то яскравість світіння в напівперіод, коли напруга дорівнювало нулю, істотно залежала від природи електроліту.

Виникнення світіння в анодний напівперіод напруги на оксидної плівці $\mathrm{Al}_{2} \mathrm{O}_{3}$ природно, так як воно обумовлено дією електричного поля. Виникнення спалаху світіння в напівперіод, коли напруга відсутня можна пояснити на підставі зроблених раніше припущень про механізм світіння люмінофорів в контакті з електролітом [272]. Необхідно відзначити, що світіння при збудженні електричним полем припиняється до встановлення нульової напруги на зразку. За решту полупериода напруги до його поверхні продовжують надходити негативні іони електроліту, які утворюють домішкові рівні донорної природи. Однак, в цей час позитивні іони електроліту $H^{+}$ще не можуть надходити до 
поверхні плівки $\mathrm{Al}_{2} \mathrm{O}_{3}$, так як діюче електричне поле все ще перешкоджає цьому. У момент часу $t_{0}$, коли напруга стає рівною нулю, досягається деяка концентрація заповнених електронами донорних центрів адсорбційної природи. При $t>t_{0}$ до зразка починають надходити позитивні іони електроліту, що утворюють на поверхні оксидної плівки акцепторні рівні з локалізованими на них дірками, в результаті чого стає можливим іонізація центрів світіння. Рекомбінація електронів, що надходять 3 донорних центрів, 3 іонізованими центрами свічення призводить до випромінювання світла.

На підставі вище викладеного розглянемо математичну модель поведінки кривих яскравості світіння. Так як оксид алюмінію $є$ широкозонним напівпровідником, то наявність вільних електронів в зоні провідності, в основному, визначається природою і концентрацією донорних центрів, в даному випадку гідроксильних груп $O H^{-}$. Тому в нашому випадку інтенсивність світіння ( $B$ ) визначається випромінювальними переходами електронів, кількість яких пропорційна кількості адсорбованих негативних іонів електроліту $\left(N_{1}\right)$ i іонізованих центрів світіння $\left(R_{0}-R\right)$, тобто можна записати:

$$
B=q N_{1}\left(R_{0}-R\right)
$$

де $R_{0}$ - загальна кількість центрів світіння, $R$ - кількість неіонізованих центрів світіння, $N_{1}$ - кількість адсорбованих негативних іонів електроліту на домішкових рівнях в момент часу $t, q$ - коефіцієнт рекомбінації.

Зміна кількості іонізованих центрів свічення в одиницю часу можна представити таким чином:

$$
\frac{d\left(R_{0}-R\right)}{d t}=a N_{2} R-b N_{1}\left(R_{0}-R\right),
$$

де $N_{2}$ - кількість адсорбованих позитивних іонів електроліту на домішкових рівнях в момент часу $t, a$ і $b$-коефіцієнти пропорційності.

Відзначимо, що розглянутий нами пік світіння спостерігається при $0,5 T<t \square T$, де $T-$ період напруги, що збуджує. В момент часу $0,5 T=t$ 
кількість іонізованих центрів свічення дорівнює нулю, i тому при малих значеннях $t$ кількість іонізованих центрів світіння буде визначатися тільки адсорбованими позитивними іонами електроліту,

Тобто $a N_{2} R \square b N_{1}\left(R_{0}-R\right)$ і тоді можна записати:

$$
\frac{d\left(R_{0}-R\right)}{d t}=a N_{2} R .
$$

Припускаємо, що ймовірність термічного викиду дірок з центрів свічення в валентну зону практично дорівнює нулю.

Зміна кількості позитивних іонів електроліту на центрах адсорбційної природи в рамках теорії Ленгмюра можна представити таким чином:

$$
\frac{d N_{2}}{d t}=\alpha\left(N_{02}-N_{2}\right)-\beta N_{2},
$$

де $\alpha\left(N_{02}-N_{2}\right)$ - кількість адсорбованих позитивних іонів електроліту за одиницю часу, $-\beta N_{2}$ - кількість десорбованих позитивних іонів електроліту 3 поверхні плівки $\mathrm{Al}_{2} \mathrm{O}_{3}$ за одиницю часу, $\mathrm{N}_{02}$ - загальна кількість центрів адсорбційної природи, $\alpha$ і $\beta$ - коефіцієнти, які мають сенс швидкості адсорбції і десорбції.

Інтегруючи вираз (1) при початкових умовах $N_{2}=0 ; t=0$, отримуємо:

$$
N_{2}(t)=\frac{\alpha N_{02}}{\alpha+\beta}[1-\exp -(\alpha+\beta) t] .
$$

Тоді зміна кількості іонізованих центрів свічення в одиницю часу:

$$
\frac{d\left(R_{0}-R\right)}{d t}=a R \frac{N_{02}}{1+\frac{\beta}{\alpha}}[1-\exp -(\alpha+\beta) t] .
$$

Інтегруючі вираз (3) 3 урахуванням початкових умов $R=R_{0}, t=0$ отримуємо:

$$
R=R_{0} e^{-k t} e^{-\frac{k}{m} e^{-m t}}
$$

де $m=\alpha+\beta, k=\frac{a N_{02}}{1+\frac{\beta}{\alpha}}$. 
Зміна кількості адсорбованих негативних іонів електроліту $\left(\mathrm{OH}^{-}-\right.$груп) на поверхні плівки $\mathrm{Al}_{2} \mathrm{O}_{3}$ :

$$
\frac{d N_{1}}{d t}=-\gamma N_{1}
$$

де $-\gamma N_{1}-$ кількість негативних іонів електроліту, що десорбується 3 поверхні люмінофора за одиницю часу, $\gamma$ - коефіцієнт, який має сенс швидкості десорбції негативних іонів електроліту.

В даному випадку, при малих значеннях часу після встановлення нульової напруги на плівці, внаслідок того, що поверхня в анодний напівперіод напруги заряджається негативно, до досліджуваної плівці починають надходити позитивні іони електроліту i, отже, можна знехтувати процесами адсорбції негативних іонів електроліту.

Виходячи початкових умов $N_{1}=N_{01}, t=0$ і інтегруючі вираз (5), отримуємо:

$$
N_{1}=N_{01} e^{-\gamma t}
$$

Отже, рівняння для визначення інтенсивності світіння, $з$ урахуванням отриманих виразів для $N_{1}$ i $\left(R_{0}-R\right)$, рівнянь (4) i (6), відповідно набуває вигляд:

$$
B=q N_{01} R\left[1-e^{-k t} e^{-\frac{k}{m} e^{-m t}}\right] e^{-\gamma t} .
$$

Аналіз функції (7) показує, що функція $B(t) 3$ часом проходить через максимум, причому час, при якому спостерігається максимум світіння, визначається процесами адсорбції і десорбції іонів електроліту на поверхні плівки $\mathrm{Al}_{2} \mathrm{O}_{3}$. Проведений аналіз експериментальних і розрахункових кривих дав гарний збіг.

На підставі розглянутого механізму виникнення піку світіння в напівперіод, коли напруга дорівнює нулю, можна пояснити частотну залежність яскравості світіння, що спостерігається в цей напівперіод. 
При малих частотах за напівперіод позитивної напруги, що подається, встигають заповнитися рівні на поверхні люмінофора аніонами і аж до деякого значення частоти з їі ростом інтенсивність практично не буде змінюватися. Подальше зростання частоти призводить вже до того, що іони $\mathrm{OH}^{-}$не встигають заповнити всі центри на поверхні люмінофора. Отже, менша кількість електронів прорекомбінує випромінювальне з іонізованими центрами світіння.

Як зазначалося раніше, при збільшенні частоти відбувається не тільки зменшення інтенсивності світіння, а й зміщення положення максимуму світіння в область більш довгих часів. Зсув максимуму обумовлено тим, що час, коли спостерігається максимум світіння, визначається тільки адсорбцією і десорбцією іонів електроліту на поверхні окисної плівки алюмінію і не залежить від частоти напруги, що подається. 3 ростом частоти напівперіод буде зменшуватися і тому час спостереження максимуму буде зміщуватися в область великих часів по відношенню до тривалості напівперіоду.

Вивчення кінетики світіння показало також істотну роль типу електроліту на інтенсивність світіння. Так як інтенсивність світіння визначається, в основному, адсорбційними процесами на поверхні плівки в електроліті, то в залежності від коефіцієнтів активності іонів електроліту інтенсивність світіння буде зменшуватися або збільшуватися. В електролітах з більш активними іонами (розчини $\mathrm{NaCl}, \mathrm{KCl}, \mathrm{NaBr}$ ) відбуваються більш активно адсорбційні процеси і інтенсивність світіння в них буде більше, ніж при вимірах інтенсивності світіння в менш активних електролітах (розчинах $\mathrm{KBr}, \mathrm{NaI}$ ), що володіють, відповідно, меншою адсорбційною здатністю. Необхідно почеркнуть, що істотний вплив природи електроліту позначається тільки на спалах світіння, що спостерігається в напівперіод, коли напруга відсутня.

Таким чином, на підставі розглянутих вище експериментально отриманих залежностей кривих кінетики світіння можна зробити висновок, що за виникнення світіння плівок $\mathrm{Al}_{2} \mathrm{O}_{3}$, поміщених в електроліт, відповідальні іони електроліту обох знаків і світіння обумовлюється випромінювальними 
переходами електронів, що поставляються негативно зарядженими іонами електроліту, адсорбованими на поверхні оксидної плівки. Причому, кількість іонізованих центрів світіння пропорційна кількості адсорбованих позитивних іонів електроліту на поверхні люмінофора. Необхідно відзначити, що вид описаної вище кінетики світіння спостерігається у всіх люмінофорів, у яких залежність інтенсивності світіння від величини $p H$ проходить через максимум, так як за виникнення світіння в напівперіод, коли напруга дорівнювала нулю, відповідальні іони електроліту обох знаків.

Раніше нами показано вплив природи електроліту на інтенсивність світіння ряду люмінофорів в контакті з електролітом. Проводилися дослідження впливу концентрації аміаку, перекису водню розчинених у водних розчинах на інтенсивність люмінесценції оксидних плівок алюмінію, занурених в ці розчини. Показано, що істотний вплив на чутливість визначення концентрації аміаку в електролітах надає технологія отримання плівок. У даній роботі представлені результати дослідження впливу концентрації аміаку, розчиненого у водних розчинах, на інтенсивність люмінесценції люмінофорів, занурених в ці розчини. Запропоновано механізм світіння, що враховує залежність інтенсивності світіння від концентрації речовини, розчиненої в електроліті. Зміну яскравості світіння можна пояснити тім, що додавання аміаку в розчин призводить до зміни величини $p H$, яке в свою чергу призводить до збілышення інтенсивності люмінесценції. Поріг чутливості зменшується 3 ростом температури і при кімнатній температурі складає величину $10^{-11}$ моль/л.

Показана можливість створення люмінесцентного сенсора аміаку на основі оксидних плівок алюмінію для вимірювання концентрації аміаку у воді і водних розчинах, що дозволяє судити про оцінку якості очищення стічних вод 3 їх допомогою. 